International Journal of Health Sciences
Available online at http://sciencescholar.us/journal/index.php/ijhs
Vol. 3 No. 3, December 2019, pages: $25 \sim 32$
e-ISSN: 2550-696X, p-ISSN: $2550-6978$
https://doi.org/10.29332/ijhs.v3n3.348

\title{
Radiation Dosage Distribution in Area Room CT Scan Multi Slice 64 to Dose Limit Value
}

\begin{abstract}
(1) CrossMark
Ni Nyoman Ratini a, I Made Yuliara ${ }^{\text {b }}$, Ni Luh Putu Trisnawati ${ }^{c}$

Article history: Received 09 May 2019, Accepted: 31 August 2019, Published: 26 October 2019

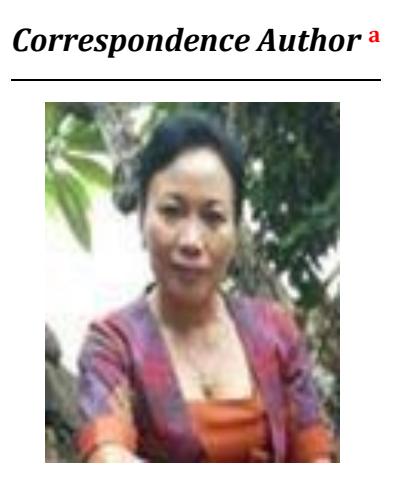

Keywords

CT scan 64; dosage rate; dose limit value; multi-slice; radiation;

\section{Abstract}

An analysis of the distribution of radiation doses in the area of CT Scan MultiSlice 64 has been carried out in Sanglah Hospital Denpasar. The study was conducted by dividing the area around the room into 8 regions and paths that indicate the distance from the wall to the surveillance. Measurements were made at several points at intervals of $1 \mathrm{~m}$. Each point is taken three times the data collection. From the results of the distribution analysis it was found that there was an increase in the radiation dose rate to the Dose Limit Value (DLV) with a significance level below 0.05 occurring in region $\mathrm{C}$ with an average dose rate of $142.32 \mu \mathrm{Sv} / \mathrm{h}$, region $\mathrm{E}$ with an average value of an average of $111.36 \mu \mathrm{Sv} / \mathrm{h}$ and area D with an average value of $40.68 \mu \mathrm{Sv} / \mathrm{h}$ which has a value above the DLV. Whereas the value of the dose rate of other regions is below the DLV. Areas with a $25 \mathrm{~cm}$ transverse brick type barrier wall that has a $2 \mathrm{~m}$ window above have an average dose rate of $129.55 \mu \mathrm{Sv} / \mathrm{h}$, a $5 \mathrm{~cm}$ wooden door with a $2 \mathrm{~mm}$ Pb layer has an average dose rate of $67,91 \mu \mathrm{Sv} / \mathrm{h}$. Whereas in areas with a $25 \mathrm{~cm}$ transverse brick type borderless wall construction without glass, $\mathrm{Pb}$ glass and reinforced concrete columns there was no increase in the radiation dose rate to the DLV. The increase in the radiation dose rate occurs because there is a window above the dividing wall and the construction of the door that is not in accordance with the rules because it has a keyhole and door handles that allow radiation to pass through the window and keyhole.
\end{abstract}

e-ISSN: 2550-696X, p-ISSN: 2550-6978 ๑ Copyright 2019. The Author. SS Journals Published by Universidad Técnica de Manabí. This is an open-access article under the CC BY-SA 4.0 license (https://creativecommons.org/licenses/by-sa/4.0/) All rights reserved.

\section{Contents}

Abstract

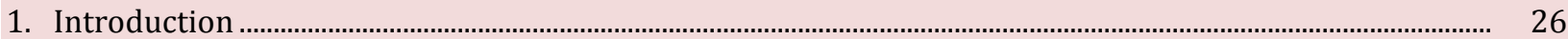

2. Materials and Methods ............................................................................................................................................. 26

a Universitas Udayana, Denpasar, Indonesia

b Universitas Udayana, Denpasar, Indonesia

c Universitas Udayana, Denpasar, Indonesia 


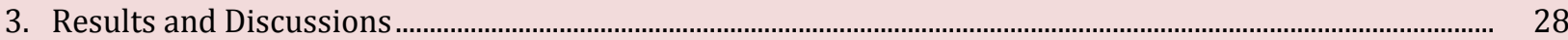

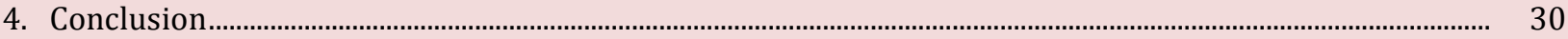

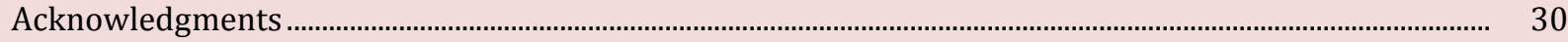

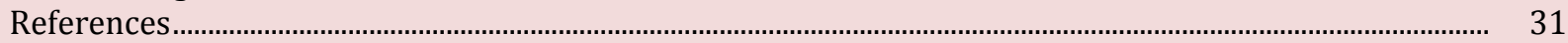

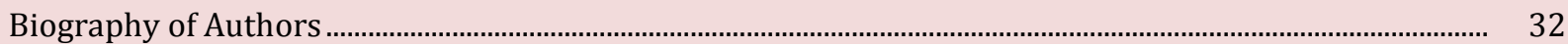

\section{Introduction}

Sodickson et al., (2009), utilization of ionizing radiation, including X-rays in the health sector both for therapy and diagnostics, has been growing ever since the discovery of X-rays in 1895 by Wilhelm Conrad Roentgen (Akhadi, 2000). The production of radiology equipment ranging from conventional radiography aircraft to sophisticated CT Multi-Slice Scans makes many contributions not only to the expansion of scientific knowledge and diagnostic capabilities of radiology but also in radiation protection for patients, officers and the environment (Bruening, et al., 2006; Sutapa et al., 2018).

The provision of radiation must be as low as possible in accordance with clinical needs is an important aspect of radiological diagnostic services that need continuous attention. Because during the X-ray radiation penetrating the material or material collisions occur with photons of atoms that cause ionization, this event can cause radiation effects on the body, both nonstochastic and stochastic (Akhadi, 2000; Noa et al., 2018).

Thus, continuous efforts are needed for occupational safety and health in the field of ionizing radiation through radiation protection measures, whether in the form of environmental radiation survey activities, personal monitoring, installation of radiation hazard alarm instruments, making standard work procedures for radiation, to repairing radiation source rooms (McNitt-Gray, 2002; Pantos et al., 2009). All these activities are useful to minimize the level of radiation dose received by radiation workers, patients and the environment around the radiation source.

One of the diagnostic imaging modalities for diagnosis is CT Multi-Slice 64 which has high accuracy in showing the structure of human organs. The operation of this tool uses a fairly large radiation dose, where the rate of X-ray radiation during irradiation can be measured using a surveillance meter in various locations around the radiation field (Seeram, 2001; Vallejo et al., 2019).

Because the radiation dose used is quite large, the determination of the room to put the CT Scan Multi-Slice 64 device must not be arbitrary must follow the rules of radiation protection. For this reason, it is necessary to analyze the distribution of the radiation dose rate in the area of the 64 Slice CT Scan tool against the Dose Limit Value (DLV) at Sanglah Hospital Denpasar.

\section{Materials and Methods}

This research took place in the Multi-Slice 64 CT Scan Sanglah Hospital in Denpasar. The research variable is the radiation dose rate as the dependent variable. As an independent variable is a location around the examination room divided into 8 regions and paths that indicate the distance between the retaining wall and the surveillance with a point varying intervals of $1 \mathrm{~m}$, one point is made 3 times the data collection. The control variable is the CT Scan examination parameter and the type of survey as well as the calibration factor and date. The confounding variable is background radiation (Suomalainen et al., 2009; Hunold et al., 2003).

The research tools and materials include a properly calibrated CT Scan, measurement using a survey with operational parameters CT Scan kV: 120, mA: 356, mAs: 300, Scan Time: 7s, Normal open collimation, Inspection protocol: Head Routine Study. The concept of appropriate research in Figure 1. 


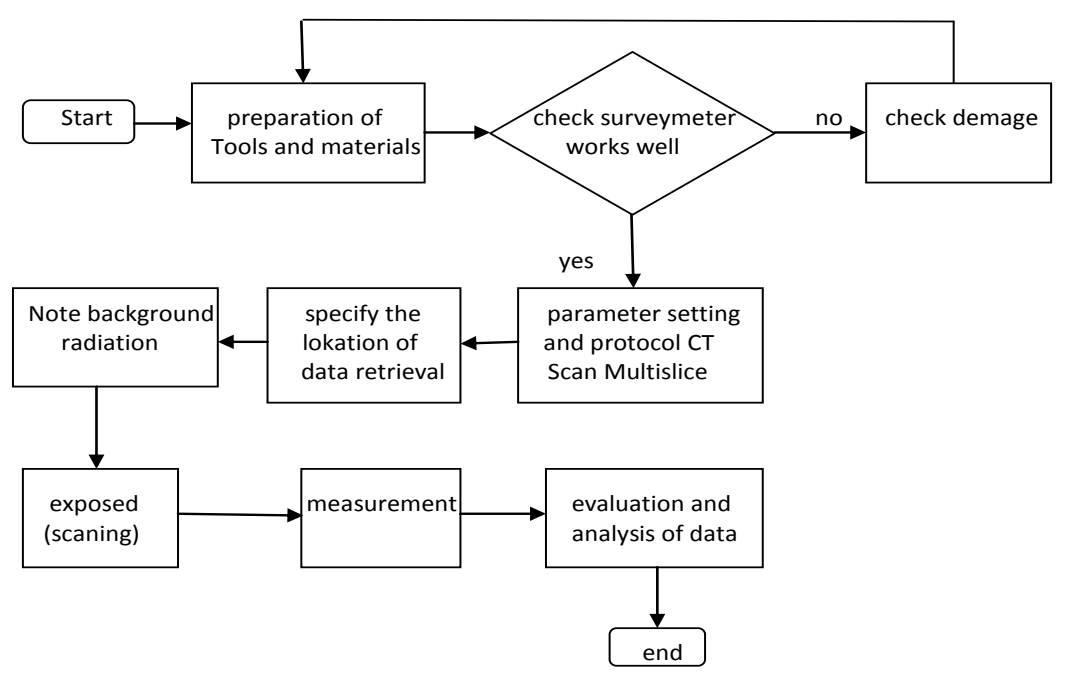

Figure 1. The concept of research

Retrieval of data follows the layout and illustration of the placement of the collection points according to Figure 2 .

\begin{tabular}{|c|c|c|c|c|c|c|c|c|}
\hline D.4.2 & D.4.1 & E.4.1 & E.4.2 & E.4.3 & E.4.4 & E.4.5 & F.4.1 & F.4.2 \\
\hline D.3.2 & D.3.1 & E.3.1 & E.3.2 & E.3.3 & E.3.4 & E.3.5 & F.3.1 & F.3.2 \\
\hline D.2.2 & D.2.1 & E.2.1 & E.2.2 & E.2.3 & E.2.4 & E.2.5 & F.2.1 & F.2.2 \\
\hline D.1.2 & D.1.1 & E.1.1 & E.1.2 & E.1.3 & E.1.4 & E.1.5 & F.1.1 & F.1.2 \\
\hline C. 2.5 & C.1.5 & & & & \multirow{5}{*}{ SOURCE } & & G.1.1 & G.2.1 \\
\hline C.2.4 & C.1.4 & & & & & & G.1.2 & G.2.2 \\
\hline C.2.3 & C.1.3 & & & & & & G.1.3 & G.2.3 \\
\hline C.2.2 & C.1.2 & & & & & & G.1.4 & G.2.4 \\
\hline C.2.1 & C.1.1 & & & & & H.1.1 & H.1.2 & H.1.3 \\
\hline B.1.2 & B.1.1 & A.1.4 & A.1.3 & A.1.2 & A.1.1 & H.2.1 & H. 2.2 & H.2.3 \\
\hline B.2.2 & B.2.1 & A.2.4 & A.2.3 & A.2.2 & A.2.1 & H.3.1 & H.3.2 & H.3.3 \\
\hline B.3.2 & B.3.1 & A.3.4 & A.3.3 & A.3.2 & A.3.1 & H.4.1 & H.4.2 & H.4.3 \\
\hline B.4.2 & B.4.1 & A.4.4 & A.4.3 & A.4.2 & A.4.1 & H.5.1 & H.5.2 & H.5.3 \\
\hline
\end{tabular}

Figure 2. Illustration of the floor plan and data collection points. The area is marked with the letter $\mathrm{A}-\mathrm{H}$, the path is marked on the second digit 1-5, the taking point on the third digit

The material and construction of the walls of each area are different from the others. Area A at point 1 consists of a $25 \mathrm{~cm}$ thick transverse brick wall, Pb glass $2 \mathrm{~mm}$ thick at points 2 and 3, Pb coated $2 \mathrm{~mm}$ wooden door at point 4 . Regions B, D, F retaining wall of the reinforced concrete column. Area C of the $25 \mathrm{~cm}$ transverse brick wall is a $2 \mathrm{~m}$ high window. Area E points 1 and 2 are $2 \mathrm{~mm}$ Pb-coated wooden doors, while points 3-5 of a $25 \mathrm{~cm}$ brick wall with a window above. $\mathrm{G}$ and $\mathrm{H}$ areas of $25 \mathrm{~cm}$ transverse brick without windows.

Ratini, N. N., Yuliara, I. M., \& Trisnawati, N. L. P. (2019). Radiation dosage distribution in area room CT scan multi slice 64 to dose limit value. International Journal of Health Sciences, 3(3), 25-32. 


\section{Results and Discussions}

The measured dose rate in the Multi-Slice 64 CT Scan room is reduced by background radiation then multiplied by the calibration factor then averaged. The radiation dose rate distribution is made in the form of mapping the radiation dose value using Matlab 7.0 software, the results of the radiation dose rate contour distribution are shown in Figure 3 below.

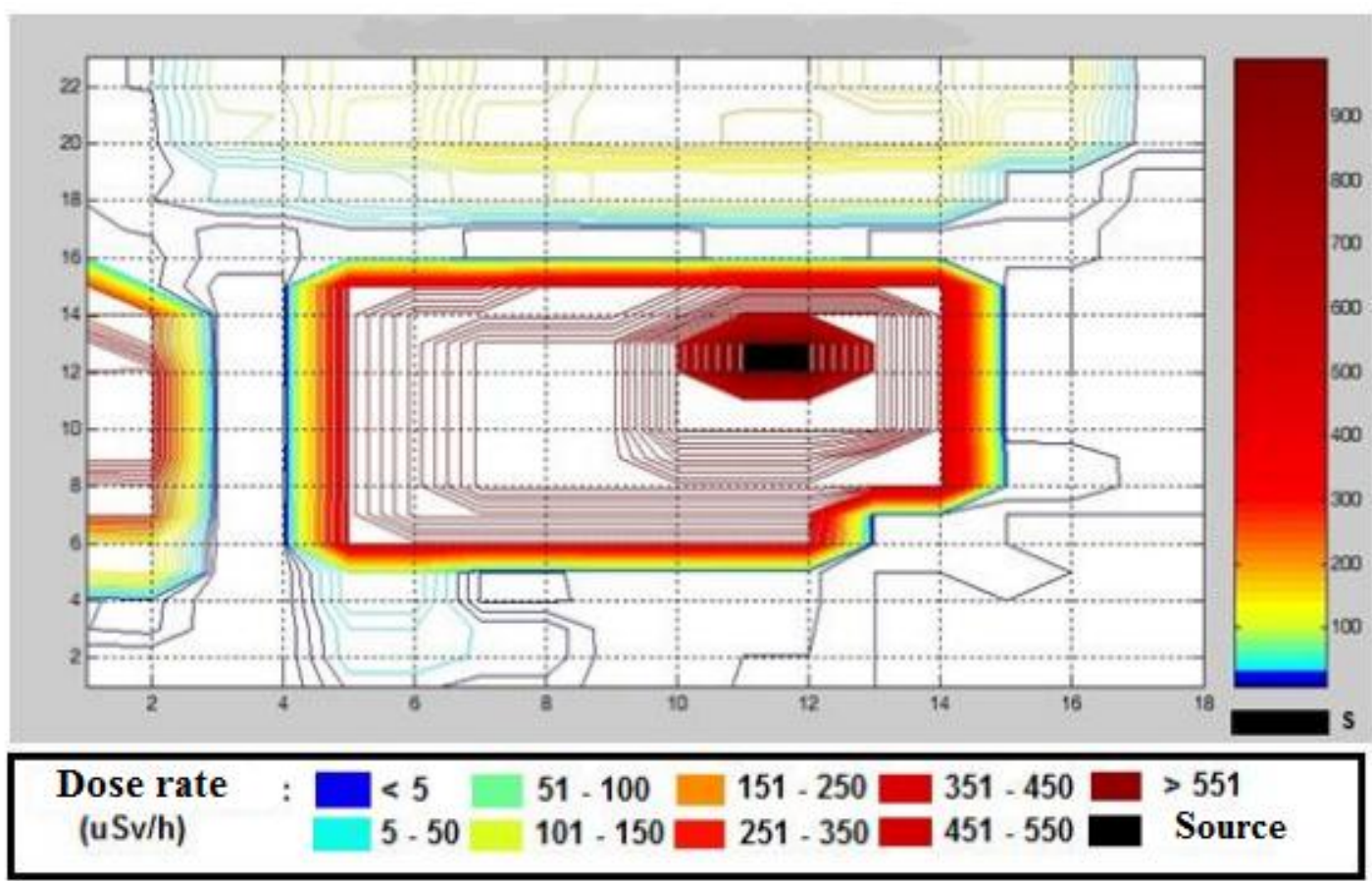

Figure 3. The distribution of radiation in the CT Scan Multi-Slice 64 room at Sanglah Hospital

The radiation mapping results in Figure 3 state that area $\mathrm{C}$ has the highest radiation dose rate marked with a red color bar in the range 251-350 $\mu \mathrm{Sv} / \mathrm{h}$, then the $\mathrm{E}$ region is marked with a yellow color bar in the range 101-150 $\mathrm{SSv} / \mathrm{h}$. For Regions D, F, and A are marked with a light blue color bar, while regions G, B and H are marked with a dark blue color bar.

Analysis of the measured radiation dose rate to the DLV is done by comparing each region, path and retaining wall construction at each point to the radiation DLV per hour, by converting an annual DLV of 20 $\mathrm{mSv} /$ year (Bapeten, 2013), into units per hour which is 5,325 $\mu \mathrm{Sv} / \mathrm{h}$.

Statistical tests using the two-way ANOVA method of the Post Hoc Test (Gunawan, 2014), can be seen in the comparison of the radiation dose rates of each region to the DLV, the results of multiple comparisons explain the comparison of the dose rate values of each region to the DLV, can be seen in Table 1.

Table 1

Test results Post Hoc Multiple Comparisons test Comparison dose rates radiation of each region against DLV

\section{Multiple Comparisons}

Dependent Variable : Radiation dose rate $(\mu \mathrm{Sv} / \mathrm{h})$

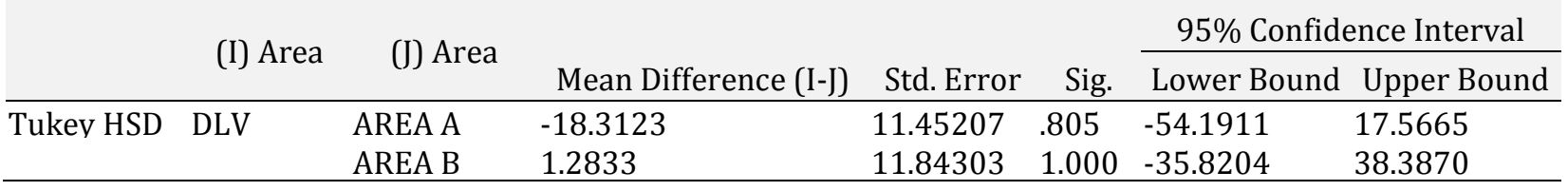




\begin{tabular}{llllll} 
AREA C & $-142.3280^{*}$ & 11.67262 & .000 & -178.8978 & -105.7582 \\
AREA D & $-40.6817^{*}$ & 11.84303 & .020 & -77.7854 & -3.5780 \\
AREA E & $-111.3605^{*}$ & 11.32411 & .000 & -146.8384 & -75.8826 \\
AREA F & -36.3404 & 11.84303 & .060 & -73.4441 & .7633 \\
AREA G & .7292 & 11.84303 & 1.000 & -36.3745 & 37.8329 \\
AREA H & 4.7661 & 11.44146 & 1.000 & -31.0795 & 40.6117 \\
\hline
\end{tabular}

Based on observed means.

The error term is Mean Square(Error) $=480.883$.

*. The mean difference is significant at the .05 level.

From Table 1 it can be seen that the regions C, D, and E are above DLV with a significance level below 0.05 and are marked with a star code above the mean. There are three areas to the value of the average dose under $\mathrm{DLV}$, ie the area $\mathrm{H}, \mathrm{B}$ and $\mathrm{G}$ with a significance of more than 0.05 , which means the difference in the radiation dose rates of the three rooms is not significant to the DLV that is set, while 5 other area has value of dose rate average higher than DLV with the highest value in area C has a significant level of 0.00 , which means that the value of the radiation dose of the room is above the DLV which is very significant. It is known based on a comparison of the average radiation dose value of area C of $142.32 \mu \mathrm{Sv} / \mathrm{h}$ higher than the determined DLV. Area E with a significance of 0.00 and has an average radiation dose rate of $111.36 \mu \mathrm{Sv} / \mathrm{h}$ higher than DLV. Then area D has a significance of 0.02 with an average radiation dose rate of $40.68 \mu \mathrm{Sv} / \mathrm{h}$ higher than DLV. For a comparison of radiation dose rates between wall constructions, see Table 2.

Table 2

Value dose rates at barrier wall construction

\begin{tabular}{|c|c|c|c|c|c|c|c|}
\hline \multicolumn{8}{|c|}{ Multiple Comparisons } \\
\hline \multicolumn{8}{|c|}{ Dependent Variable : Radiation dose rate } \\
\hline & \multirow{2}{*}{$\begin{array}{c}\text { (I) } \\
\text { Point }\end{array}$} & \multirow{2}{*}{ (J) Point } & \multirow[b]{2}{*}{$\begin{array}{l}\text { Mean Difference } \\
(\mathrm{I}-\mathrm{J})\end{array}$} & \multirow[b]{2}{*}{$\begin{array}{l}\text { Std. } \\
\text { Error }\end{array}$} & \multirow[b]{2}{*}{ Sig. } & \multicolumn{2}{|c|}{$\begin{array}{c}\text { 95\% Confidence } \\
\text { Interval }\end{array}$} \\
\hline & & & & & & $\begin{array}{l}\text { Lower } \\
\text { Bound }\end{array}$ & $\begin{array}{l}\text { Upper } \\
\text { Bound }\end{array}$ \\
\hline \multirow[t]{5}{*}{$\begin{array}{l}\text { Tukey } \\
\text { HSD }\end{array}$} & DLV & $\begin{array}{l}25 \mathrm{~cm} \text { brick wall winthout } \\
\text { windows }\end{array}$ & 3.5183 & 11.26497 & 1.000 & -28.8686 & 35.9052 \\
\hline & & Pb glass & -27.1714 & 11.42157 & .168 & -60.0085 & 5.6657 \\
\hline & & Reinforced concrete columns & -3.3112 & 11.47477 & 1.000 & -36.3013 & 29.6789 \\
\hline & & $25 \mathrm{~cm}$ brick wall with windows & $-129.5529^{*}$ & 11.26497 & .000 & -161.9398 & -97.1660 \\
\hline & & Wooden door $5 \mathrm{~cm}$ with $2 \mathrm{~mm} \mathrm{~Pb}$ & $-67.9131^{*}$ & 11.47477 & .000 & -100.9032 & -34.9230 \\
\hline
\end{tabular}

Based on observed means.

The error term is Mean Square(Error) $=480.883$.

*. The mean difference is significant at the .05 level.

From Table 2 it is known that the $25 \mathrm{~cm}$ brick wall is in area $\mathrm{C}$ and area $\mathrm{E}$ has a window above it, has a value of the radiation dose rate above the DLV with a signification below 0.05 then followed by a $5 \mathrm{~cm}$ Pb plated $2 \mathrm{~mm}$ equivalent to $2 \mathrm{~mm}$ contained in area A and area G. Construction of the wall using the window giving the results of the dose rate above the DLV with a significance level below 0.05. From the direct observation of the area $\mathrm{C}$ and $\mathrm{E}$, namely the hallway and patient waiting areas, there are glass windows at a height of 2 meters with a width of 1 meter along the dividing wall of the room. Whereas in other areas there are no windows on the dividing wall, in other words, the wall has a homogeneous material or the same constituents.

The increase in DLV that occurs in areas that are declared unsafe around the CT Scan Multi-Slice Room 64 RSUP Sanglah because of the window above the dividing wall, is characterized by statistical analysis in two

Ratini, N. N., Yuliara, I. M., \& Trisnawati, N. L. P. (2019). Radiation dosage distribution in area room CT scan multi slice 64 to dose limit value. International Journal of Health Sciences, 3(3), 25-32. https://doi.org/10.29332/ijhs.v3n3.348 
areas with a significance level below 0.05 namely $\mathrm{C}$ and $\mathrm{E}$ have a window at top of the dividing wall, while in the $\mathrm{G}$ and $\mathrm{H}$ regions that have windowless barrier construction have a dose rate below DLV. In the mapping, it was found that there were several points whose dose rate values were above the DLV, including the door area, which means the door was not up to standard and needed radiation protection treatment, also strengthened by statistical analysis which stated that the dose rate of wooden doors in areas A and F were located. above DLV with a significance level below 0.05 .

\section{Conclusion}

From the results of the measurement of the dose rate and the analysis of the distribution of radiation in the CT Multi-Slice 64 room in Sanglah Hospital Denpasar it can be concluded that there is an increase in the radiation dose rate to the Dose Limit Value (DLV) with a significance level below 0.05 occurring in regions C, regions $\mathrm{E}$ and region D with an average dose rate of $142.32 \mu \mathrm{Sv} / \mathrm{h}, 111.36 \mu \mathrm{Sv} / \mathrm{h}$ and $40.68 \mu \mathrm{Sv} / \mathrm{h}$ above the DLV. While the comparison of the value of the dose rate other areas are under DLV. The increase in the radiation dose rate occurs because there is a window above the dividing wall and door construction that does not comply with the rules because it had the keyhole and door handles that allow the radiation passes through the window and the keyhole.

\section{Acknowledgments}

The authors would like to thank Udayana University for funding this research through the Leading Research Scheme from the Study Program, the year 2019. 


\section{References}

Akhadi, M. (2000). Dasar-dasar proteksi radiasi. Jakarta: Rineka Cipta, 41.

Bapeten. (2013). Surat Keputusan Kepala Bapeten No.4 tentang Proteksi Radiasi dan Keselamatan Radiasi dalam Pemanfaatan Tenaga Nuklir. Jakarta.

Gunawan, S. (2014). U.S. Patent No. 8,665,227. Washington, DC: U.S. Patent and Trademark Office.

Hunold, P., Vogt, F. M., Schmermund, A., Debatin, J. F., Kerkhoff, G., Budde, T., ... \& Barkhausen, J. (2003). Radiation exposure during cardiac CT: effective doses at multi-detector row CT and electron-beam CT. Radiology, 226(1), 145-152.

Kuettner, A., \& Flohr, T. (2006). Protocols for multislice CT. R. Bruening (Ed.). Springer.

McNitt-Gray, M. F. (2002). AAPM/RSNA physics tutorial for residents: topics in CT: radiation dose in CT. Radiographics, 22(6), 1541-1553.

Noa, AP, Perez, AV, Hechavarria, JM, \& Santos, RD (2018). Energy interpretation of solar radiation affects for Artemisa province. International Journal of Physical Sciences and Engineering, $2(2), \quad 39-$ 49. https://doi.org/10.29332/ijpse.v2n2.142

Pantos, I., Patatoukas, G., Katritsis, D. G., \& Efstathopoulos, E. (2009). Patient radiation doses in interventional cardiology procedures. Current cardiology reviews, 5(1), 1-11.

Seeram, E. (2015). Computed Tomography-E-Book: Physical Principles, Clinical Applications, and Quality Control. Elsevier Health Sciences.

Sodickson, A., Baeyens, P. F., Andriole, K. P., Prevedello, L. M., Nawfel, R. D., Hanson, R., \& Khorasani, R. (2009). Recurrent CT, cumulative radiation exposure, and associated radiation-induced cancer risks from CT of adults. Radiology, 251(1), 175-184.

Suomalainen, A., Kiljunen, T., Kaser, Y., Peltola, J., \& Kortesniemi, M. (2009). Dosimetry and image quality of four dental cone beam computed tomography scanners compared with multislice computed tomography scanners. Dentomaxillofacial Radiology, 38(6), 367-378.

Sutapa, G. N., Yuliara, I. M., \& Ratini, N. N. (2018). Verification of dosage and radiation delivery time breast cancer (Mammae Ca) with ISIS TPS. International Journal of Health Sciences, 2(2), 78-88. https://doi.org/10.29332/ijhs.v2n2.174

Vallejo, R. S. R., Gámez, M. R., Espinales, A. M. S., \& Pérez, A. V. (2019). Effects of thermal radiation using wood stoves on population health. International Research Journal of Management, IT and Social Sciences, 6(5), 18. https://doi.org/10.21744/irjmis.v6n5.656

Ratini, N. N., Yuliara, I. M., \& Trisnawati, N. L. P. (2019). Radiation dosage distribution in area room CT scan multi slice 64 to dose limit value. International Journal of Health Sciences, 3(3), 25-32. https://doi.org/10.29332/ijhs.v3n3.348 


\section{Biography of Authors}

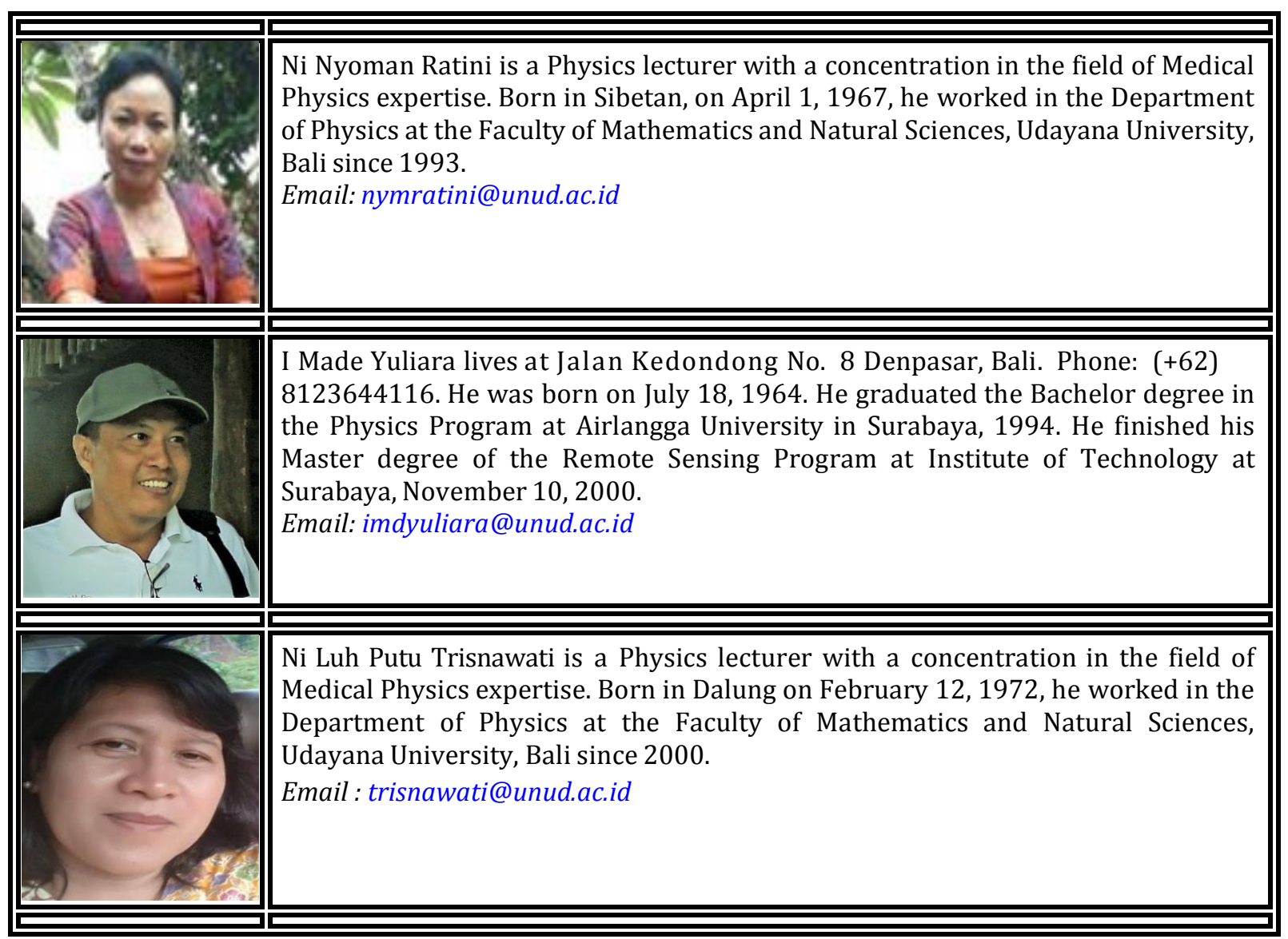

